Hajir Tajiri: Ikhtiar Mengembangkan Performance Dakwah Hasanah dari Perspektif Etika Dakwah

\title{
Ikhtiar Mengembangkan Performance Dakwah Hasanah dari Perspektif Etika Dakwah
}

\author{
Hajir Tajiri
}

Dakwah yang baik dapat dikenali melalui performance-nya. Performance dakwah hasanah merupakan sebuah wujud empirik yang dikenali dari pengalaman-pengalaman sejarah dakwah masa lalu maupun kekinian. Upaya mewujudkannya, sangat utama jika mengindahkan prinsip-prinsip etika dalam dakwah. Beberapa prinsip etika dakwah dapat dijabarkan antara lain kualitas personal dan kemampuan profesional dalam berdakwah, pemahaman tugas dan fungsi sebagai pendakwah, penguasaan ideal materi dakwah dan ideal cara mendakwahkannya. Selain itu ideal penguasaan metode dakwah dan ideal kemampuan membangun jaringan dakwah.

\author{
Kata Kunci: \\ Dakwah Hasanah, Etika Dakwah, Kualitas Personal \\ dan Kompetensi Profesional
}

\section{Pendahuluan}

Dakwah merupakan sebuah aktivitas kemanusiaan. Dalam beberapa segi baik dilihat dari segi tujuan, motivasi maupun hasilnya sangat sejalan dengan prinsip dasar hidup kemanusiaan. Dari segi tujuan, dakwah Islam merupakan serangkaian usaha untuk menata perilaku manusia agar memiliki budi pekerti dan perangai hidup yang rahmah-penuh kasih sayang antar sesama, saling nasihat menasihati dalam keshabaran dan kebenaran, saling tolong menolong dalam kebajikan dan ketakwaan; dari segi motivasi dakwah bersumber dari adanya kesadaran yang mendalam, adanya suara hati yang membisikan 
kepedulian, penerimaan terhadap nilai-nilai luhur yang diajarkan agama Islam bahwa hidup itu untuk beramal shaleh, menciptakan sebanyakbanyaknya amal manfaat yang berguna bagi kemaslahatan hidup umat manusia; demikian juga dengan hasil yang dicapai berupa terwujudnya insan-insan berkepribadian dan berahlakul karimah. Kesemua itu seiring dan sejalan dengan perasaan-perasaan manusia yang universal; sejalan dengan akal sehat dan kebutuhan-kebutuhan mendasar manusia pada umumnya.

Berpijak pada nilai-nilai utama yang menggerakan kelangsungan dakwah, maka dakwah perlu ditampilkan dengan wajah yang cantik dan menarik. Logikanya sangat sederhana, karena Islam itu ajaran yang mengajarkan kemuliaan hidup, maka ia harus diperkenalkan dengan cara yang mulia juga. Nilai-nilai utama dakwah tidak boleh dikotori oleh pikiran-pikiran dan perasaan yang busuk. Nilai-nilai rahmah, keshabaran, kesucian dan kemurnian suara hati, nilai kebenaran dan kejujuran, tolong menolong dalam kebajikan dan taqwa merupakan nilai utama yang pantang dikotori dengan niat kotor, motivasi busuk berupa amarah dan kebencian terhadap sesama. Niat, motivasi, sikap dan perilaku yang berlawanan dengan nilai-nilai utama hanya akan mencedarai kemuliaan agama, merendahkan martabat sendiri dan melukai perasaan orang yang menjumpainya.

Inilah rahasiah kesuksesan dakwah generasi terdahulu. Islam mampu tersebar dari satu tempat ke tempat lain, dari satu kota ke kota lain, dari satu jazirah ke jazirah lain, dan ke berbagai tempat di seluruh penjuru bumi karena daya tarik yang ditampilkan oleh para pembawanya yaitu para da'i yang berkepribadian mulia. Abu Zahrah dalam bukunya yang dialihbahasakan oleh Ahmad Subandi ${ }^{1}$, di antaranya dapat dikutip sebagai berikut,

"Moral Islam senantiasa menjadi senjata pendamping kepada kekuatan pertempuran dan dakwah Islamiyah. Keadilan yang dilakukan pibak yang menang terhadap kaum yang kalah dan keberadaannya senantiasa dapat menyentuh kalbu meraksuk sukma. Dari jiwa-jiwa yang pasrah dan lulub itu memancar cahaya kebaikan, sedangkan dari hati yang keras membaja atau

${ }^{1}$ Abu Zahrah, Dakwah Islamiyah, terj. Ahmad Subandi, (Bandung: Rosda Karya, 1994), h. 7. 
Hajir Tajiri: Ikhtiar Mengembangkan Performance Dakwah Hasanah dari Perspektif Etika Dakwah

lebih dari itu akan tampil keimanan yang kuat dan mantap serta paripurna. Perlakuan baik dan bijaksana yang dilakukan oleh pibak kaum muslimin (pibak yang menang) terhadap pibak yang kalah dapat membuka hati mereka untuk menerima bidayah Islam. Kecekatan dan kegesitan para pendahulu kaum muslimin menjadi kasih dan rahmat di hati kaum kafirin. Demikian pula, keadilan, komitmen, kejujuran, kesetiaan, amanah, penghormatan, dan ablak mulia mereka menjinakan singa yang buas dan melulubkan kalbu yang keras. Kelemablembutan yang memancar dari orangorang beriman menarik dan tidak melabirkan kontroversial keluwesan antara sesama orang-orang yang beriman".

Pandangan Abu Zahrah tersebut menunjukkan adanya bukti di balik keberhasilan dakwah umat Islam masa lalu yakni terletak pada keagungan, kemuliaan pribadi para pendakwah. Perhatikan juga fakta masuk Islamnya beberapa pengikut non-muslim terdahulu. Sebagaimana dijelaskan Abbas Asiisiy ${ }^{2}$ (1995): Pertama, masuk Islamnya orang-orang Hami, penduduk Afrika Utara (Tunisia) pernah ditaklukan pada masa Utsman bin Affan, kepada mereka khalifah memperlakukan mereka sebagai muallaf. Mereka diberi harta dari baitul mal sebesar kebutuhannya, dikirim beberapa guru mengajarkan bahasa Arab serta menjelaskan pengertian dan hakikat Islam. Akhirnya mereka semua masuk Islam dan menjadi tentara-tentara pembela Islam yang berhasil menaklukan Spanyol. Kedua, masuk Islamnya Usaid bin Hudhair. Ia adalah seorang tokoh/pemimpin salah satu suku di Arab pada masa tersebarnya Islam di Jazirah Arab. Proses masuk Islamnya terjadi setelah ia tertarik dengan sikap dan perilaku Mush'ab bin Umair ra. Yakni karena kelebihan sifat dan sikap yang dimiliki Mush'ab yaitu: ia memiliki wajah tampan dan berpenampilan menarik, berkata halus, lemah lembut , memahami sifat, watak dan tabe'at objek dakwahnya, dan mampu menggugah perasaan lawan bicaranya. Ketika Usaid didatangi oleh Mush'ab dengan maksud menyampaikan ajaran Allah, pada awalnya Usaid menghadang dengan amarah dan bahkan mendampratnya seraya berkata: "tinggalkan kami, jika kalian masih menyayangi nyawa kalian!". Setelah kemarahan itu terhenti, mulailah Mush'ab berkata dengan sangat halus:'bagaimana jika anda sudi duduk terlebih dahulu dan

${ }^{2}$ Abbas Asiisiy, Bagaimana Menyentuh Hati, (Solo: Intermedia, 2006), h. 83. 
mendengarkan perkataan kami. Jika anda suka ambilah, tetapi jika tidak tinggalkanlah".

Karena Mush'ab berlaku adil, Usaid pun mendengarkan. Mush'ab memberitahukan dan menjelaskan kepadanya tentang Islam dan membacakan ayat-ayat suci Al-Qur'an. Setelahnya Usaid kemudian berkata:"Demi Allah, kami sudah melihat pada wajahnya pancaran cahaya Islam sebelum ia berkata dengan wajah yang lebih ceria. Alangkah indabnya ajaran ini'. Kemudian Usaid mandi, membersihkan pakaiannya dan mengucapkan dua kalimah syahadat.

Fakta-fakta di atas cukup menjadi dasar dan pelengkap pembahasan bahwa dakwah mutlak perlu dilakukan dengan menjunjung tinggi ahlakul karimah serta kepribadian yang menarik.

Seperti halnya dalam sejarah awal Islam, penulis berasumsi dan berkeyakinan bahwa tersebarnya Islam di tanah air Indonesia pun ditopang karena para da'i yang dikenal Wali Songo itu mampu menampilkan usaha dakwahnya secara arif dan bijak dan mampu mewakili perasaan kebutuhan dari para khalayak mad'unya. Para da'i datang dengan membawa sesuatu yang dipandang sangat berharga, memenuhi kebutuhan perasaannya seperti perasaan, aman dan tentram, memberikan isi dan makna terhadap relung-relung hati yang gersang dan tidak tentu arah.

Penjelasan-penjelasan di atas mengantarkan pada fokus pembahasan, bahwa etika diperlukan dalam dakwah, khususnya dalam upaya menggapai performance dakwah yang hasanah.

\section{Etika Dakwah sebagai Ideal Konsep Pelaksanaan Dakwah}

Secara sederhana, konsep etika dipahami sebagai sesuatu yang harus dilakukan ${ }^{3}$. Berdasarkan pemahaman ini maka dalam konteks dakwah, kata 'sesuatu' mengisyaratkan adanya tuntunan, ajaran, aturan main yang bersifat normatif, ketentuan-ketentuan ideal atau kaidahkaidah yang harus dimiliki, dipedomani, dipatuhi dan dilaksanakan oleh pendakwah dalam proses dakwah.

Sejalan dengan itu, masih menurut Bertens, etika mempunyai tiga arti: pertama, nilai-nilai dan norma-norma moral yang menjadi

\footnotetext{
${ }^{3}$ K. Berten, Etika, (Jakarta: Gramedia Utama, 2005), h. 6.
} 
pegangan bagi seseorang atau suatu kelompok dalam mengatur tingkah lakunya. Kedua, etika berarti kumpulan asas atau nilai moral yakni kode etik. Ketiga, etika mempunyai arti ilmu tentang yang baik atau buruk. Dalam hal ini dikatakan sebagai ilmu, bila kemungkinan-kemungkinan etis (asas-asas dan nilai-nilai tentang yang dianggap baik dan buruk), seringkali tanpa disadari-menjadi bahan refleksi bagi suatu penelitian sistematis dan metodis ${ }^{4}$.

Ketika diterapkan untuk bidang dakwah, etika menjadi orientasi bagi usaha da'i atau da'iyah untuk menjawab pertanyaan fundamental mengenai "bagaimana seorang da'i seharusnya hidup dan melaksanakan tugas profesionalnya“. Bisa juga disebutkan sebagai usaha kritis dengan menggunakan akal budi dan daya pikirnya untuk memecahkan masalah bagaimana da'i atau da'iyah harus melaksanakan tugas profesionalnya jika ia mau menjadi baik. Jadi etika dalam konteks dakwah bertujuan antara lain: pertama, agar para pendakwah atau yang sedang berusaha menekuni profesi dakwah dapat memahami nilai-nilai kebaikan sebagai standar, patokan, tolok ukur perbuatan dalam berdakwah ; kedua, para pendakwah mampu menganalisis baik buruknya perbuatan dakwah secara kritis dan mendalam; ketiga, para pendakwah dapat melakukan evaluasi secara normatif baik buruknya perbuatan dakwah, dan keempat, para pendakwah terdorong untuk berusaha menjadikan nilai-nilai yang utama mendarah daging pada dirinya dan dapat membentuk karakter, watak, tabe'at serta kepribadian sebagai karakter personal dan profesional para pelaku dakwah ${ }^{5}$.

Dalam memaknai atau memberikan arti kepada etika dakwah, sebenarnya telah banyak para pakar di bidang ilmu dakwah yang memberikan kontribusi pemikirannya. Para pakar itu sebut saja namanamanya antara lain Syukriadi Sambas, Syukrianto, Amin Abdullah, Yunan Yusuf, Jalaludin Rakhmat, dan lain-lain ${ }^{6}$. Mereka umumnya memaknai etika dakwah sebagai hal-hal yang seharusnya dimiliki para

\footnotetext{
${ }^{4}$ Idem

5 Hajir Tajiri dan Enjang AS, Etika Dakwah Suatu Pendekatan Teologis dan Filosofis, (Bandung: Widya Padjadjaran, 2009), h. 15.

${ }^{6}$ Aris Rifanudin, Etika Tablig, (Bandung: Fakultas Dakwah dan Komunikasi, 2007), 17.
} 
pendakwah. Hal-hal tersebut dijabarkan sebagai kriteria ideal pendakwah yang berkait dengan kepribadian dan tugas pokok serta fungsinya; berkait dengan ideal materi dakwah; berkait dengan ideal hubungan pendakwah dan yang didakwahi; ideal bagaimana semestinya menyusun materi dakwah; ideal bagaimana semestinya menyampaikan atau melakukan dakwah; ideal bagaimana semestinya menggunaka metode dan media dakwah.

\section{Kriteria Ideal yang Penting dimiliki Pendakwah}

Salah satu faktor yang tidak bisa diabaikan oleh seorang pendakwah jika dakwahnya ingin diterima adalah berkait dengan ideal penampilan dan kepribadian. Dalam peribahasa sunda sering dikenal bade gogog hade tagog, peribahasa ini tanpaknya bukan sekedar basa basi melainkan ril adanya dan bisa dibuktikan kebenarannya secara ilmiah.

Penampilan sangat berpengaruh terhadap meningkatkan daya tarik seseorang. Menurut Deddy Mulyana ${ }^{7}$ (2001), aspek penampilan yang berpengaruh terhadap daya tarik itu sekurang-kurangnya dapat dibagi atas dua bagian yaitu: penampilan luar (fisik) dan penampilan dalam (kepribadian).

Pertama, penampilan luar (fisik), meliputi: (1) busana, baik berupa model, kualitas bahan, warna, ornamen, serta assesoris lain yang dikenakan seperti: kaca mata, sepatu, tas, jam tangan, kalung, gelang, cincin, anting, dan sebagainya; (2) karakteristik fisik seperti: kecantikan/ketampanan, warna kulit, postur tubuh, bentuk tubuh, model rambut, kondisi tubuh: cape-lelah, cacat-sempurna.

Aspek penampilan luar/fisik yang berpengaruh terhadap daya tarik ini telah banyak diteliti oleh sejumlah ahli. Misalnya, penilitian yang dilakukan Dion, Berscheid, dan Harold Sigall tentang pengaruh wajah cantik. Menurut Dion dan Berscheid, orang-orang cantik/tanpan umumnya dinilai lebih berhasil di dalam hidupnya dan dianggap memiliki sifat-sifat yang baik. Kemungkinan karena daya tarik sering menjadi penyebab utama atraksi personal. Orang begitu senang terhadap orang-orang tanpan/cantik, dan pada gilirannya kemudian

${ }^{7}$ Deddy Mulyana, Ilmu Komunikasi Suatu Pengantar, (Bandung: Remaja Rosda Karya, 2001),h. 346. 
sangat mudah memperoleh simpati dan perhatian orang. Orang cantik /tanpan juga dinilai lebih epektif dalam mempengaruhi pendapat orang lain dan diperlakukan sopan. Bukti menunjukkan perusahaan umumnya menggunakan wanita-wanita cantik bukan saja untuk promosi dan iklan melainkan juga untuk menjadi petugas hubungan masyarakat (Deddy Mulyana, ).

Secara lebih empirik Harold Laswell juga melaporkan hasil eksperimennya untuk membuktikan pengaruh kecantikan dalam komunikasi. Dalam penelitiannya Harold menyuruh seorang wanita untuk mewawancarai beberapa mahasiswa. Langkah-langkah yang ditempuh; pertama dengan membagi mahasiswa menjadi dua kelompok. Pada kelompok pertama, wanita itu tampil sebagai wanita cantik dan pada kelompok lainnya ia tampil sebagai wanita yang jelek. Hasilnya sangat menakjubkan, ketika ia tampak sebagai wanita cantik, penilaian para mahasiswa kelompok satu sangat baik dan positif, dan dengan penilaian itu para mahasiswa sangat menyenanginya, sebaliknya ketika wanita itu tanpak jelek pada kelompok lainnya, penilaian mahasiswa yang jelek menyebabkan mereka membencinya ${ }^{8}$.

Demikianlah penjelasan ilmiah yang menerangkan pengaruh penampilan fisik, dengan penampilan itu bukan hanya menyebabkan seseorang diterima akan tetapi juga bisa menjadikan dakwah lebih epektif.

Dalam Islam masalah penampilan ini sebenarnya juga diakui dan diajarkan, Abu Hurairah r.a. , meriwayatkan :"Ada seorang laki-laki tampan yang datang kepada rasulullah lalu berkata,"ya Rasulullah, sesunggubnya saya adalah orang yang suka keindahan dan saya telah diberi oleb Allah keindaban itu, seperti yang engkau saksikan, sampai-sampai saya tidak suka jika ada orang yang melebihi saya meskipun hanya berupa sandal jepit. Apakah ini termasuk sifat sombong?" Rasulullah menjawab,"tidak, sesunggubnya yang dimaksud sifat sombong adalah menolak kebenaran dan meremebkan orang lain" (HR. Abu Daud) ${ }^{9}$.

${ }^{8}$ Ibid

${ }^{9}$ Abbas Asiisiy, Op.Cit., h.82. 
Menurut Abbas Asiisiy ${ }^{10}$ sejarah mencatat sahabat-sahabat nabi yang berparas tanpan dan berpostur tubuh sangat gagah: Dahyah AlKalbi yang diutus menemui Heraklius sebagai delegasi, Ia mempunyai postur tubuh yang baik dan wajah yang tampan. Mush'ab bin Umair juga berwajah tampan dan berpenampilan menarik. Ibundanya adalah wanita kaya raya, ia biasa membelikan sebaik-baik pakaian dan sebaikbaik wewangian. Demikian pula dengan Ja'far bin Abu Thalib.

Kata Abbas As-Siisyi lebih lanjut, semenjak dahulu, para penghulu, para da'i, tatkala duduk di hadapan majelisnya senantiasa mengenakan baju terindah, menaburinya dengan aroma wewangian, dan mengenakan dandanan yang mampu mempesona. Diantara mereka adalah Abdullah bin Abbas, Abu Hanifah, Imam Malik dan Imam Syafi'i.

Kedua, penampilan dalam arti kepribadian. Menurut Newcomb ${ }^{11}$ , Kepribadian adalah organisasi sikap-sikap yang dimiliki seseorang sebagai latar belakang terhadap perilaku. Ia juga merupakan organisasi faktor-faktor biologis, psikologis dan sosiologis. Sedang secara sederhana kepribadian bisa dimaknai sebagai sifat yang khas yang dimiliki seseorang yang berkembang apabila orang tadi berhubungan dengan orang lain.

Beberapa faktor biologis yang mempengaruhi kepribadian antara lain: sistem syaraf, watak seksual, proses pendewasaan dan kelainan biologis. Faktor-faktor psikologis yang berpengaruh terhadap kepribadian: unsur temperamen, kemampuan belajar, perasaan, keterampilan, keinginan. Sedangkan faktor sosiologis, sangat tergantung pada kemampuan seseorang untuk bersosialisasi atau menyesuaikan dirinya dengan tuntutan lingkungan sekitarnya atau sistem nilai yang dianut masyarakatnya ${ }^{12}$.

\footnotetext{
${ }^{10} \mathrm{I}$ bid

11 Soekanto, Sosiologi Suatu Pengantar, (Jakarta: Raja Grafindo Persada, 1999),h.202.

${ }^{12}$ Ibid
} 


\section{Kepribadian Sang Pendakwah}

Seseorang (da'i) dituntut mampu menjaga dan merawat kepribadian positifnya dan mampu mengkondisikan pengaruh-pengaruh agar menunjang terhadap lahirnya kepribadian yang baik, misal dengan cara mengaturnya.

Ada beberapa kepribadian ideal yang relevan dimiliki oleh pendakwah. Kepribadian ideal itu oleh Yunan Yusuf diistilahkan dengan kriteria normatif. Menurut Yunan Yusuf ${ }^{13}$ (sebagaimana dikutip oleh Subhi dalam tulisannya di http://www.ahmad_subhi.co.id), kriteria ideal/ kriteria normatif yang harus dimiliki pendakwah adalah sebagai berikut:

1. Memiliki kepribadian Rabbani

Menurut kriteria ini, seorang pendakwah hendaknya memiliki sifat seperti yang dimiliki Sang Khaliq (takhalaqu biakblaqillab). Allah Maha Kasih Sayang dan Maha Pelembut. Rahmatnya mendahului adzabnya. Maka perwujudannya dalam pribadi pendakwah, hendaknya motivasi utama dakwah berangkat dari dasar perasaan kasih sayang, bukan motif-motif lain apalagi kebencian atau balas dendam. Demikian pula dalam memperlakukan para mad'u yang didakwahinya.

2. Memiliki kepribadian Malaki

Para malaikat seperti diilustrasikan dalam al-Qur'an, merupakan mahluk yang selalu taat kepada perintah Allah, tidak pernah membantah atau mendurhakai-Nya. Implementasinya pada pribadi pendakwah, ia selalu menjaga dan membawa diri agar senantiasa berada dalam ridha Allah dengan memperbanyak dzikir dan beribadah kepada Allah.

3. Memiliki kepribadian qur'ani

Al-Qur'an merupakan kitab pedoman bagi manusia, di dalamnya berisi tuntunan hidup, petunjuk, dan berbagai informasi penting tentang kehidupan. Oleh karena sudah sewajarnya seorang pendakwah sangat mencintai kitab sucinya, membacanya, menghayatinya, dan mengamalkannya dalam segenap kehidupan pribadinya.

\footnotetext{
${ }^{13}$ Yunan Yusuf dalam Ahmad Subhi, Membentuk Perilaku Kader Mubaligh yang Taat Etik, Internet: http:// www.ahmad_subhu.co.id
} 
4. Memiliki kepribadian rasuli

Menurut Rakhmat ${ }^{14}$,yang dimaksud kepribadian rasuli adalah kepribadian sebagai penyampai risalah, antara lain: shiddiq (mencintai kebenaran), amanah (menjaga amanah), fatonah (pintar dan cerdas), hamiyyah (menjunjung harga diri), tawadhu (merendahkan diri), judd (dermawan), syajaah (keberanian), buzn (prihatin), iqtishad (hemat), ikbtiraz (waspada), hadiyyah (gemar memberi), 'afw (gemar memaafkan), raja' (pengharapan pada Allah), riqqah al-qolb (hati yang lembut), tawakkal (berserah diri kepada Allah setelah berusaha), ikhtiyat (hatihati), mubadarah (bersegara dalam melakukan amal shaleh), ikhbar al-hal (tempat curahan hati umat).

5. Memiliki kepribadian yaumil akbiri

Keyakinan akan adanya yaumil akhir akan sangat berpengaruh terhadap kepribadian. Keyakinan akan yaumil akhir akan membentengi perilaku seseorang untuk tidak terjerumus berbuat dosa dan kemaksiatan. Keyakinan akan yaumil akhir dapat menjadikan seseorang memiliki pandangan yang jauh ke depan, dan mampu mempertimbangkan segala sesuatu di atas prinsip keselamatan hidup di masa yang akan datang. Apa jadinya tugas dakwah jika hakikat pesan dakwah, pengembangan dan penyampaiannya tidak didasarkan pada pribadi diri pendakwah sendiri yang seharusnya menjadi model bagi umat.

6. Memiliki kepribadian qadari

Keyakinan qadari merupakan salah satu indikasi keimanan seseorang bahwa dalam hidup ini berlaku ukuran-ukuran dan ketentuan ilahiyah. Seseorang mesti meyakini bahwa selain usaha dirinya ada juga dimensi lain yang akan menentukan nasib hidupnya. Untuk itu selain usaha juga banyak menyandarkan kepada sang kholiq melalui do'a yang dipanjatkan agar nasib hidupnya senantiasa berada dalam kebaikan.

7. Memiliki kepribadian Syahadatain

Ikrar syahadatain atau ikatan yang mengokohkan dirinya untuk senantiasa kukuh dalam komitmen bathinnya untuk tidak berpaling dari menuhankan Allah dan mengikuti rasul-Nya, akan mempertegas jati diri seseorang dan memperjelas sikap seseorang. Bahwa seorang pendakwah

${ }^{14}$ Aris Rifanudin, Op.Cit., h. 143. 
hendaknya senantiasa menempatkan Allah dan rasul-Nya sebagai titik tolak dan titik tuju aktivitas dakwah.

8. Memiliki kepribadian Musholli

Shalat memiliki dimensi pembelajaran ahlak yang sangat luar biasa, melalui penegakkan shalat kehidupan seseorang akan menjadi disiplin sekurang-kurangnya dengan pembiasaan pada setiap waktu shalat. Dalam shalat juga ada ketentraman bathin karena memiliki efek relaksasi yang cukup tinggi, terutama pemusatan pikiran, kepasrahan dan pengharapan yang besar kepada sang khaliq. Shalat juga akan mampu mengasah ketajaman mata bathin seseorang sehingga orang yang memelihara shalat suara hatinya selalu bening.

9. Memiliki kepribadian shoimi

Kompetensi inti dari kepribadian shoimi terletak pada kemampuannya untuk menaham dan melakukan pengendalian diri. Tidak semua yang enak itu memberikan kenikmatan dan kesenangan. Dalam beberapa hal sesuatu yang mungkin menimbulkan konsekuensi negatif di masa yang akan dating sepertinya mendatangkan kenikmatan. Misalnya mengonsumsi miras atau shabu-shabu, untuk beberapa saat mungkin bisa dinikmati kesenangannya, bisa menjadikan play in the sky, tetapi dalam jangka panjang menimbulkan kerusaksakan pada beberapa fungsi organ tubuh. Melalui shaum seseorang berharap sesuatu yang nilainya sangat tinggi walau dengan susah payah harus mampu menahan dorongan kesenangan yang menuntut penyegaraannya. Kemampuan kontrol diri penting dimiliki agar dalam meraih kesuksesan seorang pendakwah tidak terkena penyakit merasa diri sudah sempurna, atau sebaliknya dihinggapi penyakit perasaan depresi dan putus asa.

10. Memiliki kepribadian Murakki

Kompetensi inti dari kepribadian ini terletak pada kerelaan dan kesediaannya untuk berkorban, yaitu menyisihkan sebagian harta atau rizki yang dimilikinya untuk disumbangkan kepada orang lain yang membutuhkan atau untuk membiayai sarana dan aktivitas keagamaan dan kemanusiaan. Kompetensi ini penting untuk meyakinkan khalayak yang didakwahinya. Dapat dibayangkan andai si pendakwah enggan untuk menjadi muzakki bagaimana ketika ia harus meyakinkan kepada orang lain akan pentingnya menunaikan perintah ibadah zakat. 


\section{Memiliki kepribadian Hajiyyi}

Berhaji atau menyengaja pergi ke baitullah merupakan amaliyah ibadah yang memerlukan pengorbanan yang tinggi. Dengan beribadah haji terlebih bagi umat Islam di Indonesia, selain kesiapan fisik jasmani, berarti ia juga harus mampu mengorbankan sedikitnya sejumlah biaya sebanyak 30 jutaan, selain itu harus mampu mengorbankan perasaan untuk berpisah dengan anggota keluarga beberapa waktu lamanya. Sikap mental kemauan berkorban merupakan modal utama meraih kesuksesan dan termasuk juga dalam perjalanan dakwah.

12. Memiliki ablaqul karimah

Ablaqul karimah merupakan misi utama diutusnya rasul Muhammad, maka hakikat dakwah juga utamanya diorientasikan pada pelaksanaan misi itu, materi atau pesan dakwah yang disampaikan, cara menyampaikan hingga pribadi yang menyampaikan harus secara konsisten merefleksikan pencapaian ablaqul karimah itu.

13. Memiliki wawasan, dan pemahaman yang menyeluruh tentang manhaj Islam dalam berbagai dimensinya, dll.

\section{Keprofesionalan Sang Pendakwah}

Selain kriteria normatif, kriteria lainnya yang penting dimiliki pendakwah adalah kriteria professional. Kata professional merupakan predikat yang umumnya melekat atau dimiliki oleh orang yang memiliki kepiawaian, kesungguh-sungguhan, ketekunan, keuletan dalam melaksanakan tugas keprofesian yang dimilikinya. Dalam konteks dakwah predikat professional dapat diberikan kepada pendakwah yang telah mampu secara bersungguh-sungguh menjalankan profesi dakwah. Kesungguh-sungguhan ini juga mencakup sejak pendakwah mempersiapkan bekal dakwahnya hingga pelaksanaan dakwahnya. Kesungguh-sungguhan mengandung arti selalu menyempurnakan tugas keprofesiannya, menghindarkan diri dari sikap mental asal atau daripada tidak, tetapi kesungguhan itu berarti usaha keras untuk memberikan manfaat dan kepuasan bagi setiap orang yang menggunakan jasa dakwahnya.

Para ahli sedikit beragam merumuskan indikator profesional. Menurut Jalaluddin Rakhmat, beberapa kriteria professional yang harus dimiliki pendakwah antara lain kedewasaan, mencakup kedewasaan 
berpikir, berbicara, bertindak, kecerdasan emosional, kecerdasan kinestetikal, kecerdasan musical, penampilan enak dipandang, kepiawaian scientific problem solving, kepiawaian public speaking, kepiawaian membangun jaringan, kepiawaian mengungkap ide baru, kepiwaian adaptif dengan media komunikasi massa dan dalam menggunakannya ${ }^{15}$.

Predikat professional ternyata diberikan untuk menunjukkan nilai plus yang dimiliki pendakwah dalam aplikasi dakwahnya. Ada sesuatu yang membedakan antara pendakwah professional dengan yang tidak atau belum professional yaitu pada nilai kreativitas dan pengendalian. Nilai kreativitas muncul karena multi kecerdasan; dari kompetensi musikal misalnya kemampuan membuat dan mengalunkan senandung irama musik lagu, menggubah syair, memetik gitar, seruling dan lain-lain. Dari kompetensi teatrikal, seorang pendakwah mampu mengekspresikap perasaan-perasaannya melalui raut wajah, mimik muka, gerak tangan, tengadah, menunjuk, bermain peran dan lain-lain. Selain itu kemampuan membuat humor-humor segar dan menyisipkannya dalam proses dakwah. Dilihat dari aspek ini tidak semua pendakwah mampu mengembangkannya, orang-orang yang mampu menggali bakat dan melatihkannya sajalah yang akan mampu memilikinya. Dari sisi ini pula profesi dakwah pada akhirnya mampu mendatangkan keuntungan material bagi pendakwah berupa isi kocek untuk memenuhi segala keperluan hidupnya. Siapa yang mampu membantah ketika faktanya masyarakat masih cenderung memilih pendakwah professional itu untuk mengisi momentum dakwah yang dikelolanya. Inilah fakta, semakin profesional si pendakwah semakin tinggi peminat yang ingin mengundangnya, sehingga tidak jarang para pendakwah profesional itu waktu yang dimilikinya menjadi sangat terbatas karena waktu yang dimiliki tidak cukup untuk melayani membanjirnya peminat yang ingin menggunakan kemampuannya itu.

Indikator keprofesionalan yang lainnya, dapat juga dilihat dari sisi kemampuan pendakwah dalam memfungsikan dirinya di tengahtengah masyarakat. Menurut Amin Abdullah fungsi pendakwah di tengah-tengah masyarakat/ umat antara lain sebagai penyeru umat

${ }^{15}$ Jalaludin Rakhmat, Etika Tabligh Islam, Internet: http:// www.muthahhari.co.id. 
(munadi), pendidik umat (muaddib), pemersatu umat (muwabhid), pelurus informasi (musaddid), pejuang (mujabhid), pembaharu (mujaddid) ${ }^{16}$.

Selain yang disebutkan Amin Abdullah, Syukrianto juga memberikan uraian mengenai fungsi pendakwah di tengah-tengah umat. Fungsi itu antara lain: sebagai planner atau perencana kehidupan sosial umat; sebagai muara atau pusat kebijakan umat; sebagai ahli atau expert, sebagai pengontrol kehidupan umat; sebagai mediator; teladan umat; symbol of the group; pembawa kabar gembira dari Allah; teolog dan metodolog Islam; sebagai central figure umat dan sebagai agent of social change ${ }^{17}$.

\section{Ideal Materi yang mesti disampaikan dalam Dakwah}

Menurut Syukrianto ada beberapa ideal materi yang harus disampaikan dalam dakwah, yaitu: materi dakwah harus jelas rujukannya, bersumber dari Al-Qur'an dan As-Sunnah, tidak berbicara hal-hal yang mengundang perpecahan, tidak menjelek-jelekkan satu golongan dan mengangkat golongan yang lainnya, kaya dengan nuansa pencerahan, bersifat factual, menyetuh logika khalayak penerima dakwah, menyentuh dimensi human interest-nya, aktual (up to date), edukatif, tidak menjenuhkan karena kaya improvisasi yang energik dan supermotivatif ${ }^{18}$.

Selain yang disebutkan, menurut Amin Abdullah, struktur materi dakwah juga harus jelas. Struktur dakwah yang baik terdiri dari: pertama, muqoddimah (pendahuluan) yang terdiri dari; salam, fawatibul khitobah, pengantar ke topik inti, membacakan ayat rujukan. Kedua, matan dakwah, mencakup isi: ayat rujukan, hadits rujukan, menyebutkan asbabun nuzul ayat kalau ada, menjelaskan ayat dengan tafsir, menjelaskan ayat menggunakan kaidah lughowi, menggunakan kaidah ushul fiqih, menjelaskan dengan qoulun hakim (kata-kata bijak), menjelaskan dengan syair, member contoh aktual dan faktual. Ketiga,

\footnotetext{
16 Amin Abdullah, Belajar Bertabligh dari Para Nabi, Internet: http:// www.amin_abdullah.com.

17 Sukrianto, Tabligh Islam; antara Keharusan dan Kenyataan, Internet: http:// www.sukrianto.co.id.

${ }^{18}$ Idem
} 
ikhtitam, yakni penutup yang berisi; kesimpulan, himbauan aktualisasi pesan, do'a dan sejumlah saran-saran ${ }^{19}$. Dalam hal pemilihan kata juga perlu diperhatikan, antara lain hendaknya menggunakan intilah yang spesifik, menggunakan kata-kata yang sederhana dan mudah dipahami, tidak menggunakan istilah-istilah yang banyak tafsirannya, tidak mengulang-ulang kata secara berlebihan, hindari kata-kata klise, hindari bahasa yang vulgar, kata-kata penat, gunakan kata-kata berona, kutip kata-kata yang mengajarkan kebijakan, gunakan bahasa yang tidak menggurui ${ }^{20}$.

\section{Ideal Cara Penyampaian Materi Dakwah}

Cara bertutur kata seorang pendakwah akan/dapat menarik perhatian orang yang mendengar dan melihatnya, karena pada dasarnya jiwa manusia cenderung dan tertarik dengan penampilan dan tutur kata yang indah dan baik.

Untuk itu suatu kepatutan bagi pendakwah, berwaspada dalam bertutur kata terutama berpikir terlebih dahulu sebelum berkata, sebab jika perkataan telah dilontarkan bukan lagi lisan yang mengendalikan perkataan tetapi perkataan yang menghukum lisan. Tutur kata yang baik adalah tutur kata yang dilakukan secara benar, halus, lembut, tepat, epektif dan episien. Perkataan mempertimbangkan situasi kondisi. Agar tutur kata menjadi indah, kata Amin Ahsan Islahi ${ }^{21}$ (1982) ada beberapa hal yang penting diperhatikan:

a. Gunakan bahasa yang bisa dipahami, yakni bahasa yang biasa dipergunakan sehari-hari oleh penerima dakwah.

b. Jelas: tidak kabur, tidak terlalu singkat, tidak bertele-tele, tidak menggunakan istilah-istilah yang aneh.

c. Tutur yang mengandung kasih sayang, kelembutan, kejelasan, kesederhanaan, dan tidak dibuat-buat.

d. Kata-kata manis didengar dan setiap frasa berjiwa serta penuh ilham.

e. Memikat emosi agung manusia.

${ }^{19}$ Amin Abdullah, Op. Cit., h. 7.

${ }^{20}$ Idem.

${ }^{21}$ Amin Ahsan Islahi, Serba-Serbi Dakwah, (Bandung: Penerbit Pustaka, 1982), 
f. Boleh saja diimbangi dengan ekspresi wajah, mata nampak merah menyala, suara membesar, semangat meluap, terutama dalam berorasi tapi tetap harus proporsional.

g. Mengulangi perkataan yang sekira sulit ditangkap atau diterima

Seperti halnya perumusan materi dakwah, cara penyampaian materi dakwah pun perlu dipersiapkan, terutama suasana emosi yang menyertai penggunaan cara atau metode perlu benar-benar terkondisikan. Menurut Jalaludin Rakhmat, ketika seseorang berdiri untuk berdakwah, maka keadaan psikologisnya akan mengalami perubahan. Apalagi seseorang yang belum terbiasa berbicara di hadapan orang banyak. Karena itu ada beberapa hal yang mesti dipersiapkan oleh seorang pendakwah sebelum ia naik ke podium. Di antaranya adalah penguasaan mental ${ }^{22}$ (Rifanudin, 2007 : 150).

Sebelum naik podium, seorang pendakwah mesti mempersiapkan mental dan menguasai emosinya, sehingga saat berada di mimbar ia bisa dengan mudah menguasai dirinya sendiri, tidak grogi atau malu. Secara psikologis, ketenangan pembawaan seorang pendakwah, akan berpengaruh pada mental para pendengar. Keadaan mental yang tampak dari seorang pendakwah akan mempengaruhi suasana keseluruhan. Hal ini akan sangat berpengaruh pada kelancaran penyampaian dakwah. Jika diawalnya sudah mengalami hambatan psikologis, maka terlebih lagi selanjutnya. Ingatlah bahwa langkah awal menentukan langkah selanjutnya. Ketenangan mental dan pembawaan seorang pendakwah didukung oleh kesiapan penguasaan materi dakwah yang akan disampaikan .

Masih berkait dengan cara penyampaian materi, seorang pendakwahnya hendaknya mampu menggunakan corak metode secara variatif sebab jika tidak, tampilan dakwah jadi monoton, kaku, kurang atraktif, menjenuhkan, membosankan. Metode dakwah hendaknya mampu memberikan nuansa edukatif, memberikan nuansa supermotivatif. Seorang pendakwah juga hendaknya mampu menggunakan retorika.

${ }^{22}$ Aris Rifanudin, Op. Cit., h. 150. 
Hajir Tajiri: Ikhtiar Mengembangkan Performance Dakwah Hasanah dari Perspektif Etika Dakwah

\section{Ideal Penggunaan Metode Dakwah}

Dakwah yang baik (da'wah hasanah) mutlak dilakukan dengan menggunakan metode yang baik (man amara ma'rufan falyakun 'alaibi bima'rufin). Metode dakwah yang baik banyak dipaparkan oleh Jalaludin Rakhmat, antara lain: metode graduasi (tadarruj), levelisasi (mura'at almustawayat), variasi (al-tawi wa al-taghyir), keteladanan (al-uswah wa alqudwab), aplikatif (al-tathbiqi wa al-amali), pengulangan (al-takerir wa almuraja'ah), evaluasi (al-taqyim), dialog (al-biwar), cerita (al-qishah), dars (pengajaran), tamtsil (perumpamaan), uswah shalibah (keteladanan perilaku), dan lain-lain ${ }^{23}$ (Rahmat, www.muthahhari.co.id).

Bagaimana pendakwah semestinya menggunakan metode dakwah, juga dijelaskan oleh Jalaludin Rakhmat. Menurutnya ada beberapa hal yang penting diperhatikan, yaitu: kuasai dan ketahui beragam bentuk dari metode dakwah, pahami kondisi objektif medan dakwah, ketahui peta madzhab fiqih dari khalayak mad'u yang akan didakwahi, gunakan teknik dan metode dakwah yang sesuai dengan kondisi objek yang didakwahi, sebaiknya pendakwah memiliki bank pengalaman baik berupa pengalaman keberhasilan maupun kegagalan dari penggunaan suatu metode dakwah, piawai dalam menggunakan metode dakwah (Rakhmat, www.muthahhari.co.id; Rifanudin, 2007: 160).

\section{Kesimpulan}

Dakwah yang baik dapat dikenali melalui performance-nya. Indikasi performance dakwah hasanah merupakan gambaran ril yang ditemukan di lapangan, bukan merupakan asumsi atau sebuah pernyataan yang masih merupakan hipotesis. Performance dakwah hasanah merupakan sebuah wujud yang empirik yang dikenali dari pengalaman-pengalaman sejarah dakwah masa lalu maupun kekinian. Performance dakwah hasanah ditemukan pada sejumlah fakta keberhasilan dakwah baik dari sisi pendakwah maupun yang didakwahi, dan juga tidak terpisah dengan sejumlah kompetensi yang dimiliki pendakwah dan diterima secara sukarela oleh yang didakwahi.

${ }^{23}$ Jalaludin Rakhmat, Etika Tabligh Islam, Internet: http://www.muthahhari.co.id. 
Upaya mewujudkan performance dakwah hasanah, sangat utama jika mengindahkan prinsip-prinsip etika dalam dakwah. Dakwah yang menjunjung tinggi etika akan sangat memperhatikan pentingnya kualitas personal sang pendakwah di satu sisi dan kompetensi di sisi lain. Keduanya kualitas personal dan kompetensi mutlak harus dimiliki secara integrated. Kualitas personal akan mampu mengontrol dan mengatur perjalanan karir dakwah agar tetap berkembang, terhindar dari kekonyolan, dan berkontribusi bagi pengembangan skill dakwah yang diperjuangkannya.

Beberapa prinsip etika dakwah dapat dijabarkan antara lain kualitas personal dan kemampuan profesional dalam berdakwah, pemahaman tugas dan fungsi sebagai pendakwah, penguasaan ideal materi dakwah dan ideal cara mendakwahkannya. Selain itu penguasaan metode dakwah dan kemampuan membangun jaringan dakwah.

\section{Daftar Pustaka}

Abbas Asiisiy, Bagaimana Menyentuh Hati, Intermedia, Solo, 2006.

Abu Zahrah, Dakwah Islamiyah, terj. Ahmad Subandi, Rosda Karya, Bandung, 1994.

Amin Abdullah, Belajar Bertabligh dari Para Nabi, Internet: http:// www.amin_abdullah.com.

Amin Ahsan Islahi, Serba-Serbi Dakwah, Penerbit Pustaka, Bandung, 1982.

Aris Rifanudin, Etika Tablig, PRD Fakultas Dakwah dan Komunikasi, Bandung, 2007.

Deddy Mulyana, Imu Komunikasi Suatu Pengantar, Remaja Rosda Karya, Bandung, 2001.

Hajir Tajiri dan Enjang AS, Etika Dakwah Suatu Pendekatan Teologis dan Filosofis, Widya Padjadjaran, Bandung, 2009.

Jalaludin Rakhmat, Etika Tabligh Islam, Internet: http:// www.muthahhari.co.id.

K. Berten, Etika, Gramedia Pustaka Utama, Jakarta, 2005.

Soekanto, Sosiologi Suatu Pengantar, Raja Grafindo Persada, Jakarta, 1999. 
Hajir Tajiri: Ikhtiar Mengembangkan Performance Dakwah Hasanah dari Perspektif Etika Dakwah

Sukrianto, Tabligh Islam; antara Keharusan dan Kenyataan, Internet: http:// www.sukrianto.co.id.

Yunan Yusuf dalam Ahmad Subhi, Membentuk Perilaku Kader Mubaligh yang Taat Etik, Internet: http:// www.ahmad_subhu.co.id. 